\title{
Diminished Polymorphonuclear Leukocyte Adherence
}

\author{
FUNCTION DEPENDENT ON RELEASE OF CYCLIC AMP
}

BY ENDOTHELIAL CELLS AFTER

STIMULATION OF $\beta$-RECEPTORS BY EPINEPHRINE

\author{
Laurence A. Boxer, John M. Allen, and Robert L. Baehner, with the technical \\ assistance of VICKTORIA AMICK, Department of Pediatrics, Division of Pediatric \\ Hematology/Oncology, James Whitcomb Riley Hospital for Children, \\ Indianapolis, Indiana 46223
}

A B STRACT To investigate the biochemical and cellular basis for the rise in polymorphonuclear leukocyte (PMN) count during epinephrine administration, PMN from subjects receiving epinephrine were studied for their capacity to adhere to nylon wool fibers and endothelial cell monolayers. After administration of epinephrine, the PMN count increased by $80 \%$ at $5 \mathrm{~min}$, and isolated PMN adherence to nylon fibers fell from a base line of $44 \pm 2-18 \pm 3 \%$. In contrast, when subjects were infused with the $\beta$-antagonist propanolol before receiving epinephrine, the PMN count failed to rise and PMN adherence was normal. Exposure of PMN endothelial cell monolayers to 0.1 $\mu \mathrm{M}$ epinephrine led to diminished PMN adherence that could be blocked by $10 \mu \mathrm{M}$ propanolol but not by $10 \mu \mathrm{M}$ phentolamine. Sera obtained from subjects $5 \mathrm{~min}$ after receiving epinephrine or from supernates derived from endothelial cell monolayers exposed to $90 \mathrm{nM}$ epinephrine inhibited PMN adherence to nylon fibers. Addition of anticyclic AMP antisera but not anticyclic guanosine monophosphate antisera to the postepinephrine sera or to the postepinephrine supernate derived from the endothelial cell monolayers abolished their inhibitory effect of PMN adherence to nylon fibers. In contrast, direct exposure of PMN to epinephrine failed to affect their adherent properties. Because it has been previously shown that endothelial cells contain $\beta$-receptors and respond to catecholamines by raising their intracellular concentrations of cyclic AMP, and that PMN adherence is attenuated by cyclic AMP, it would appear that diminished PMN adherence after epinephrine administration is mediated through endothelial cell

Received for publication 3 October 1979 and in revised form 24 April 1980. $\beta$-receptor activity, which in turn impairs PMN margination in vivo and could account for the rise in circulating PMN.

\section{INTRODUCTION}

The fight or fright reaction incites the release of epinephrine and norepinephrine from the adrenal medulla resulting in tachycardia, bronchodilation, peripheral vasoconstriction, lymphocytosis, and neutrophilia. Polymorphonuclear neutrophil leukocytes $(\mathrm{PMN})^{1}$ labeled with diisopropyl [ $\left.{ }^{32} \mathrm{P}\right]$ fluorophosphate, when returned to their donor's circulation, distribute equally into a circulation and a marginating pool. Athens and co-workers (1) rapidly infused epinephrine into five human subjects and observed a rise in the blood PMN concentration to about twice the control levels while recovering an average of $72 \%$ of the donor diisopropyl $\left[{ }^{32} \mathrm{P}\right]$ fluorophosphate PMN, whereas, before infusion, only $50 \%$ of the cells were retrieved $(1,2)$. Although PMN are known to reversibly adhere to vascular endothelium in vivo $(3,4)$, the cellular factors regulating cell adherence to vascular endothelium (5-7) and to artificial surfaces in vitro are incompletely understood $(8,9)$. In an attempt to measure cell interaction with artificial surfaces, an in vitro assay has been developed that measures the adhesiveness between PMN and nylon fibers and recently has been shown to reflect similar adhesive properties between PMN and endothelial monolayers (5). Using both techniques for measuring PMN adhesion, we investigated the biochemical and cellular basis for impaired PMN adhesion to endothelium in

${ }^{1}$ Abbreviations used in this paper: GMP, guanosine monophosphate; PMN, polymorphonuclear leukocyte. 
vitro after epinephrine exposure. We found that diminished PMN adherence in vitro after epinephrine administration is mediated through the release of cyclic AMP by endothelial cells, which in turn could account for the rise in circulating PMN in vivo during epinephrine administration.

\section{METHODS}

In vivo studies. After obtaining informed consent, adult volunteers received $0.5-0.6 \mathrm{mg}$ of epinephrine subcutaneously; $20 \mathrm{~cm}^{3}$ of peripheral blood was obtained at $0,5,15$, and $30 \mathrm{~min}$ for total white counts and differentials as well as for PMN adherence studies. In some studies, the same subjects were given an initial dose intravenously of $5 \mathrm{mg}$ of propanolol followed by a constant infusion of propanolol $0.08 \mathrm{mg} / \mathrm{min}$ for $45 \mathrm{~min}$, at which time epinephrine was administered subcutaneously (10). To ascertain whether sera from subjects receiving epinephrine would affect PMN adherence, postepinephrine sera were recovered at varying times and freshly obtained purified PMN at $1 \times 10^{7}$ cells $/ \mathrm{ml}$ were incubated for $5 \mathrm{~min}$ in $1 \mathrm{ml}$ of the sera before passage over nylon fiber columns or before incubation with endothelial cell monolayers. The postepinephrine sera was maintained at $4^{\circ} \mathrm{C}$ before use with PMN. In some studies, as indicated in the legends to the tables, the sera was incubated 5 min with either anticyclic AMP or anticyclic guanosine monophosphate (GMP) antiserum.

PMN adherence. PMN adherence to nylon wool fibers was assayed by a modification $(8,9)$ of the method of MacGregor et al. (11). The columns were packed with $70 \mathrm{mg}$ of nylon wool to a height of $15 \mathrm{~mm}$ above the constriction of the pipette. Suspensions of PMN and erythrocytes were derived from a Ficoll-Hypaque gradient (12) and washed once in $0.15 \mathrm{M}$ $\mathrm{NaCl} .1 \mathrm{ml}$ suspension of the PMN in human AB-negative serum was incubated with various drugs for some experiments for $5 \mathrm{~min}$ before passage of the PMN over the columns. The suspensions of PMN containing between 0.8 and 2.0 $\times 10^{-7}$ cell $\mathrm{s} / \mathrm{ml}$ were applied to the top of triplicate columns and allowed to flow through by gravity at $37^{\circ} \mathrm{C}$. Comparison of pre- and postcolumn PMN counts permitted calculation of the percent of PMN adhering to the columns. Results of the triplicate columns were averaged for each blood specimen and expressed as the percent PMN adherence. The variability of PMN adherence to the nylon fibers in the three columns did not exceed $10 \%$ beyond the mean.

Cultures of human endothelial cells were prepared from human umbilical veins according to the modification of Czervionke et al. (13) of the method of Jaffe et al. (14). Cells were suspended in medium 199, with Earle's salts (M-199): $9.87 \mathrm{~g} /$ liter medium 199 powder, $2 \mathrm{mM}$ L-glutamine, $0.05 \mathrm{~g} /$ liter neomycin sulfate, $0.0025 \mathrm{~g} /$ liter fungizone (amphotericin B), and $2.2 \mathrm{~g} /$ liter $\mathrm{NaHCO}_{3}, \mathrm{pH} 7.4$ (M-199 with $20 \%$ human serum in a ratio of 8 parts M-199:2 parts human serum). The cells were seeded in $35 \times 10 \mathrm{~mm}$ petri dishes and incubated in a $5 \% \mathrm{CO}_{2}$ atmosphere at $37^{\circ} \mathrm{C}$. After $24 \mathrm{~h}$, the monolayers were washed with fresh M-199 with $20 \%$ human serum and then relayered with $2.5 \mathrm{ml}$ of the same medium. Confluent primary endothelial monolayers, containing $0.7-0.8 \times 10^{6}$ cells, were used for adherence studies 4-7 d after seeding. Cell counts were determined with a hemocytometer after suspension of the cells with $0.25 \%$ trypsin-0.05\% trisodium EDTA in phosphate-buffered saline. Purified PMN were prepared by Ficoll-Hypaque density sedimentation using the technique of Boyum (12). After separation, the PMN were washed twice in Krebs-
Ringer phosphate, $\mathrm{pH} 7.4$, and then suspended in normal AB-negative human serum at a final concentration of $0.8-2.0$ $\times 10^{7} \mathrm{PMN} / \mathrm{ml}$. After removal of the M-199 from the tissue cultures, the plates were washed twice with Dulbecco's

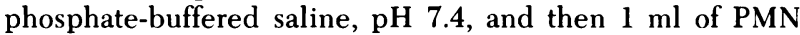
suspension was added to triplicate plates just covering the 35-mm diameter surfaces (5). The tissue culture-PMN overlay was incubated at $37^{\circ} \mathrm{C}$ in a $5 \% \mathrm{CO}_{2}$ atmosphere for varying periods of time as indicated in the legends to the tables; the suspension was then aspirated. Comparison of the PMN counts before and after incubation permitted calculation of the percentage of PMN adhering to the monolayers. In experiments evaluating the effect of drugs on the tissue culture-PMN overlay, the drugs were added directly to the experimental plates at concentrations indicated in the tables. A gentle agitation followed to assure adequate mixing. In other experiments, supernates derived from stimulated endothelial cell culture monolayers were incubated with freshly obtained $1 \times 10^{7} \mathrm{PMN} / \mathrm{ml}$ for varying periods of time before determination of subsequent PMN adherence to either nylon fiber columns or fresh endothelial cell monolayers. As indicated in the legends to the tables, anticyclic nucleotide antisera were added to the supernates for $5 \mathrm{~min}$ at $37^{\circ} \mathrm{C}$ before determination of PMN adherence. Immunofluorescence microscopy was used to demonstrate that antihemophiliac factor was present in the cells leading to their identity as endothelial cells $(14,15)$.

Reagents. Powdered medium 199 (with Earle's salts, without $\mathrm{HaHCO}_{3}$, L-glutamine, neomycin sulfate solution, and fungizone (amphotericin B) were purchased from Gibco Laboratories, Grand Island Biological Co., Grand Island, N. Y. Culture flasks, petri dishes, and plastic centrifuge tubes were purchased from Falcon Labware, Div. of Becton, Dickinson \& Co., Oxford, Calif. Phentolamine, EDTA, and epinephrine were obtained from Sigma Chemical Co., St. Louis, Mo. Injectable epinephrine was purchased from Parke, Davis, \& Co., Detroit, Mich.; propanolol hydrochloride (Inderal) injectable from Ayerst Laboratories, New York and Sigma Chemical Co.

Statistics. Statistical significance was determined by comparing drug effects with the control using the $t$ test.

\section{RESULTS}

After the subcutaneous injection of $0.5-0.6 \mathrm{mg}$ of aqueous epinephrine, the absolute PMN count rose at $5 \mathrm{~min}$ and remained elevated throughout the $30 \mathrm{~min}$ of study (Fig. 1). Purified PMN obtained at various time points showed an initial adherence of $44 \pm 2 \%$ to nylon wool fibers before epinephrine administration and then PMN adherence fell throughout the length of the study (Table I). The dose of epinephrine was sufficient to increase the cardiac rate by $15-30$ beats/min with concomitant widening of the pulse pressure. Systolic pressures rose by as much as $15 \mathrm{~mm} \mathrm{Hg}$, whereas diastolic pressures fell by $10 \mathrm{~mm} \mathrm{Hg}$. If the same subjects were treated initially with propanolol, a $\beta$ adrenergic blocking agent, followed by epinephrine, the pulse rate decreased slightly and the diastolic blood pressure rose slightly. On the other hand, the absolute PMN count increased by no $>23 \%$ at 15 min after epinephrine administration (Fig. 1). Under the latter circumstances, purified PMN obtained at various time 


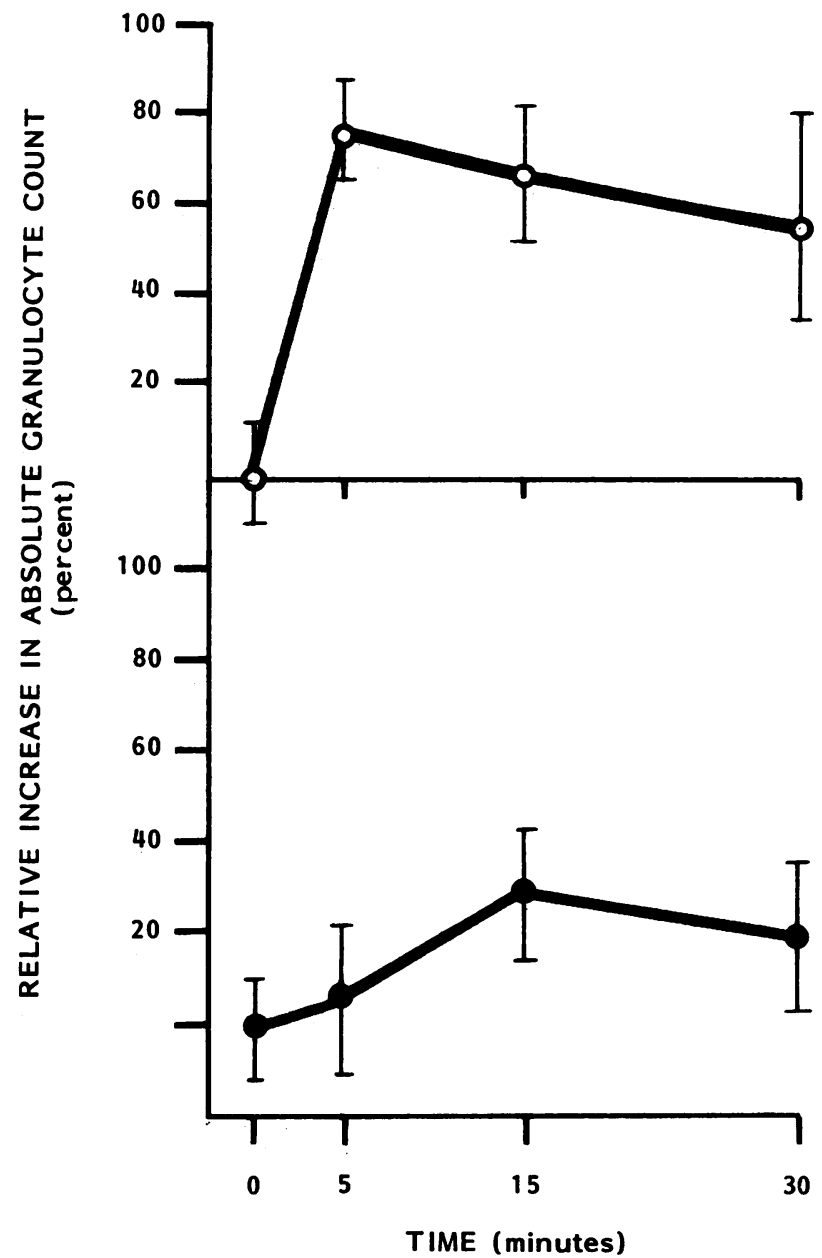

FIgure 1 The relative rise in the peripheral blood PMN count in three separate subjects after the subcutaneous administration of $0.5 \mathrm{mg}$ of aqueous epinephrine is shown in the upper panel and represented by mean \pm SD. The relative rise in peripheral blood PMN count subsequent to propanolol infusion in the same subjects followed by epinephrine injection is shown in the lower panel. The remainder of PMN counts in the lower panel are expressed relative to the zero time in the subjects treated with propanolol and epinephrine.

points maintained normal adherence to nylon wool fibers throughout the duration of the study (Table I).

Purified PMN were incubated for 5 min at $37^{\circ} \mathrm{C}$ with varying concentrations of epinephrine ranging between 10 to $0.1 \mathrm{mM}$ to establish whether the effect of epinephrine on PMN adherence to nylon fibers was mediated directly or indirectly through a soluble factor. As indicated in Table II, epinephrine failed to directly affect PMN adherence to nylon fibers. In contrast, sera obtained from the subjects receiving epinephrine diminished adherence of freshly obtained PMN from normal subjects. The sera obtained $10 \mathrm{~min}$ after epinephrine administration attenuated PMN ad-
TABLE I

Time Course of PMN Adherence to Nylon Fibers after Epinephrine Administration or Administration of Propanolol and Epinephrine

\begin{tabular}{rcc}
\hline Time & Epinephrine alone & $\begin{array}{c}\text { Propanolol then } \\
\text { epinephrine }\end{array}$ \\
\hline $\min$ & $\%$ & \\
0 & $44 \pm 2$ & $44 \pm 3$ \\
5 & $18 \pm 3$ & $41 \pm 2$ \\
15 & $23 \pm 11$ & $40 \pm 3$ \\
30 & $26 \pm 12$ & $42 \pm 4$ \\
\hline
\end{tabular}

Values in the second column represent the mean \pm SD PMN adherence to nylon wool fibers of triplicate determinations of six separate experiments on three control subjects. Values in the third column represent duplicate determinations of three separate experiments of PMN adherence after initial proponolol infusion to the same three subjects and then epinephrine administration.

herence to the greatest extent. This effect was preserved by maintaining the PMN for $1 \mathrm{~h}$ at $4^{\circ} \mathrm{C}$ before rewarming the cells to $37^{\circ} \mathrm{C}$ for $5 \mathrm{~min}$ and then passing the cells over the nylon fiber columns. Under such conditions, $\mathrm{PMN}$ adherence was $26 \pm 5 \%$. The effect of sera on PMN adherence obtained $5 \mathrm{~min}$ after epi-

\section{TABLE II}

Effect of Drugs and Postepinephrine Sera on PMN Adherence to Nylon Fibers

\begin{tabular}{ccc}
\hline Treatment & $\begin{array}{c}\text { Adherence } \\
(\text { mean } \pm \text { SD) }\end{array}$ & $P$ value \\
\hline$\%$
\end{tabular}

$\begin{array}{lcc}\begin{array}{l}\text { None } \\ \text { Epinephrine }\end{array} & 47 \pm 3(6) & \\ 0.1 \mathrm{mM} & & \text { NS } \\ 1 \mu \mathrm{M} & 45 \pm 2(6) & \mathrm{NS} \\ 90 \mathrm{mM} & 44 \pm 2(6) & \mathrm{NS} \\ \text { Postepinephrine sera } & 46 \pm 2(6) & \\ 0 \text { min } & 46 \pm 4(9) & \mathrm{NS} \\ \text { Anticyclic AMP } & 46 \pm 4(3) & \mathrm{NS} \\ \text { Anticyclic GMP } & 50 \pm 5(3) & <0.005 \\ 5 \text { min } & 32 \pm 5(3) & \text { NS } \\ \text { Anticyclic AMP } & 53 \pm 6(3) & <0.005 \\ \text { Anticyclic GMP } & 27 \pm 5(3) & <0.005 \\ 10 \text { min } & 27 \pm 2(3) & <0.01 \\ 15 \text { min } & 34 \pm 7(3) & <0.02 \\ 30 \text { min } & 38 \pm 6(3) & \end{array}$

The number in parentheses represents the number of individual studies performed in triplicate. The PMN were incubated with each of the drugs or with the postepinephrine sera, obtained at the indicated times from the subjects, for $5 \mathrm{~min}$ before passage over the nylon fiber columns. In some experiments a 1:50 dilution of either anticyclic AMP or anticyclic GMP antiserum was added to the postepinephrine sera. 
TABLE III

Effect of Endothelial Cell Monolayer Supernate on PMN Adherence to Nylon Fibers

\begin{tabular}{ccc}
\hline Treatment & $\begin{array}{c}\text { Adherence } \\
\text { (mean } \pm \text { SD) }\end{array}$ & $P$ values \\
\hline & $\%$ & \\
None & $48 \pm 4(11)$ & \\
Anticyclic AMP & $57 \pm 9(3)$ & NS \\
Anticyclic GMP & $45 \pm 1(3)$ & NS \\
Epinephrine & & \\
$0.9 \mu M$ & $19 \pm 6(3)$ & $<0.001$ \\
Anticyclic AMP & $47 \pm 8(3)$ & NS \\
Anticyclic GMP & $22 \pm 2(3)$ & NS \\
$90 \mathrm{nM}$ & $37 \pm 3(3)$ & $<0.001$ \\
$9 \mathrm{nM}$ & $49 \pm 2(3)$ & NS \\
Isoproterenol & & \\
$0.1 \mu M$ & $11 \pm 1(3)$ & $<0.001$ \\
$10 \mathrm{nM}$ & $29 \pm 7(3)$ & $<0.001$ \\
$1 \mathrm{nM}$ & $44 \pm 5(3)$ & NS \\
\hline
\end{tabular}

The number in parentheses represents the number of individual endothelial cell monolayers derived from single umbilical cords. The monolayers were covered with $1.5 \mathrm{ml}$ of fresh human serum to which the drugs were added for $5 \mathrm{~min}$ at $37^{\circ} \mathrm{C}$. After addition of the drugs, the supernates were recovered and added to fresh PMN for 5 min before passage of the PMN over the nylon fiber columns. In some experiments, a 1:50 dilution of either anticyclic AMP or anticyclic GMP antiserum was added to postepinephrine supernate.

nephrine administration was completely abrogated by anticyclic AMP antiserum but not by anticyclic GMP antiserum. Exposure of PMN to the respective antisera alone lacked effect on adherence of the cells to nylon fibers.

Because epinephrine failed to directly affect PMN but postepinephrine sera produced a marked impair- ment in PMN adherence to nylon fibers, human endothelial cells were considered a potential source for the elaboration of the soluble factor modifying PMN adherence. As noted in Table III, supernates derived from endothelial cell monolayers previously exposed to epinephrine for 5 min significantly impaired adherence of freshly obtained PMN to nylon fibers at concentrations achievable in vivo. Similarly, exposure of endothelial cell monolayers to the $\beta$-agonists epinephrine or isoproterenol resulted in supernates that impaired PMN adherence to nylon fibers. Because $\beta$-agonists are known to raise intracellular levels of cyclic AMP in endothelial cells as well as plasma levels in vivo, we studied the influence of anticyclic nucleotide antisera in supernates derived from endothelial cells previously exposed to epinephrine. Anticyclic AMP, but not anticyclic GMP, completely abolished the effect of the postepinephrine supernate on impairing PMN adherence to nylon fibers. Neither antiserum had any effect on supernates derived from unstimulated endothelial cells. Similar to the temporal effect of sera obtained from subjects exposed to epinephrine, supernate derived from endothelial cell monolayer stimulated by epinephrine impaired freshly obtained PMN adherence to nylon fibers (Table IV). The effect of the postepinephrine supernate was maximal at $5 \mathrm{~min}$ and lost by $30 \mathrm{~min}$. The preincubation of the endothelial cell monolayers with propanolol before the addition epinephrine abolished the inhibitory effect of the supernate derived from the endothelial cell monolayers.

The addition of $0.9 \mu \mathrm{M}$ epinephrine directly to endothelial cell monolayers previously incubated for 10 min with PMN led to decreased adherence of PMN to the endothelial cells. Addition of $10 \mu \mathrm{M}$ of the $\beta$-antagonist propanolol to the endothelial cell prevented the effect of epinephrine on decreasing PMN

TABLE IV

Time Course of Stimulated Endothelial Cell Monolayers Supernates on PMN Adherence to Nylon Fibers

\begin{tabular}{|c|c|c|c|c|c|}
\hline \multirow[b]{2}{*}{ Stimulant } & \multicolumn{5}{|c|}{$\begin{array}{l}\text { Adherence } \\
\text { (mean } \pm \text { SD) }\end{array}$} \\
\hline & $\mathbf{0}$ & 5 & $\begin{array}{c}\text { Time }(\min ) \\
10\end{array}$ & 15 & 30 \\
\hline & $\%$ & $\%$ & $\%$ & $\%$ & $\%$ \\
\hline $90 \mathrm{nM}$ epinephrine & $47 \pm 4(3)$ & $\begin{array}{c}20 \pm 3(3) \\
P<0.001\end{array}$ & $\begin{array}{c}26 \pm 3(3) \\
P<0.001\end{array}$ & $\begin{array}{c}32 \pm 2(3) \\
P<0.001\end{array}$ & $\begin{array}{c}45 \pm 1(3) \\
\mathrm{NS}\end{array}$ \\
\hline $\begin{array}{l}10 \mu \mathrm{M} \text { propanolol, then } \\
90 \mathrm{nM} \text { epinephrine }\end{array}$ & $47 \pm 4(3)$ & $\begin{array}{l}46 \pm 5(3) \\
\text { NS }\end{array}$ & $\begin{array}{l}53 \pm 1(3) \\
\text { NS }\end{array}$ & $\begin{array}{l}45 \pm 5(3) \\
\text { NS }\end{array}$ & $\begin{array}{c}46 \pm 2(3) \\
\text { NS }\end{array}$ \\
\hline
\end{tabular}

The number in parentheses represents the number of individual endothelial cell monolayers derived from single umbilical cords. The monolayers were covered with $1.0 \mathrm{ml}$ of fresh human serum to which propanolol was added for $2 \mathrm{~min}$ followed by epinephrine for $5 \mathrm{~min}$. After incubation with the drugs at the indicated time, the supernates were recovered and added to fresh PMN for 5 min at $37^{\circ} \mathrm{C}$ before passage of the PMN over nylon fiber columns. 
adherence (no addition, $44 \pm 3 \%$; $0.9 \mu \mathrm{M}$ epinephrine, $30 \pm 5 \% ; 10 \mu \mathrm{M}$ propanolal followed by $0.9 \mu \mathrm{M}$ epinephrine, $42 \pm 8 \%$ ). On the other hand, the addition of $10 \mu \mathrm{M}$ of the $\alpha$-antagonist, phentolamine, failed to abrogate the effect of epinephrine $(10 \mu \mathrm{M}$ phentolamine followed by $0.9 \mu \mathrm{M}$ epinephrine, on decreasing PMN adherence $34 \pm 4 \%$ ). Neither propanolol nor phentolamine by themselves had any effect on PMN adherence to endothelial cell monolayers.

To further substantiate whether the findings observed with the nylon fiber columns paralleled those obtained with the endothelial cell monolayers, freshly obtained PMN were incubated for 5 min with either postepinephrine sera obtained from subjects or postepinephrine supernates derived from endothelial cell monolayers; the subsequent adherence of the treated PMN to new endothelial cell monolayers, containing $10 \mu \mathrm{M}$ propanolol to block the effect epinephrine, was monitored. As noted in Table V, both postepinephrine conditions impaired PMN adherence similar to that observed with the nylon fibers. Incubation of PMN them-

TABLE V

Effect of Postepinephrine Sera, Postepinephrine Supernates, and Epinephrine on PMN Adherence to Endothelial Cell Monolayers

\begin{tabular}{lcc}
\hline \multicolumn{1}{c}{ Treatment } & $\begin{array}{c}\text { Adherence } \\
(\text { mean } \pm \text { SD })\end{array}$ & $P$ value \\
\hline & $\%$ & \\
In vivo & & \\
$\quad$ None & $46 \pm 4(3)$ & \\
$\quad$ Postepinephrine sera & $30 \pm 9(3)$ & $<0.01$ \\
In vitro & & \\
$\quad$ None & $46 \pm 3(3)$ & \\
$\quad$ Postepinephrine supernate & $30 \pm 4(3)$ & $<0.01$ \\
$\quad$ Saline, wash & $42 \pm 1(3)$ & \\
$\quad$ Epinephrine, wash* & $18 \pm 6(3)$ & $<0.005$ \\
\end{tabular}

The number in parentheses represents the number of individual endothelial cell monolayers derived from single umbilical cords. The PMN from three different subjects were incubated for $5 \mathrm{~min}$ at $37^{\circ} \mathrm{C}$ with postepinephrine sera obtained $5 \mathrm{~min}$ after the administration of $0.5 \mathrm{mg}$ epinephrine subcutaneous, or the PMN were incubated for 5 min at $37^{\circ} \mathrm{C}$ with postepinephrine supernates obtained $5 \mathrm{~min}$ after exposure of endothelial cell monolayers to $90 \mathrm{nM}$ epinephrine. The PMN suspended in either the postepinephrine sera or supernate were added to fresh endothelial cell monolayers for 10 min and then the number of adherent PMN determined. * Endothelial cell monolayers were exposed to $0.9 \mu \mathrm{M}$ epinephrine or $10 \mu \mathrm{l}$ saline suspended in $1.0 \mathrm{ml}$ fresh sera for $5 \mathrm{~min}$ at $37^{\circ} \mathrm{C}$. The supernate was removed; phosphate-buffered saline, $\mathrm{pH} 7.4$, was added to the cell suspension and then removed; fresh PMN suspended in $1.0 \mathrm{ml}$ fresh serum were added for $10 \mathrm{~min}$ before determination of PMN adherence. selves with $90 \mathrm{nM}$ epinephrine for $5 \mathrm{~min}$ followed by a wash in phosphate-buffered saline and resuspension of the PMN in normal sera failed to attenuate PMN adherence to the endothelial cell monolayers (data not shown). On the other hand, if the endothelial cell monolayers were directly incubated with epinephrine for $5 \mathrm{~min}$ in the presence of serum, washed with phosphate-buffered saline and a fresh PMN suspension in serum added, $\mathrm{PMN}$ adherence to the stimulated monolayer was significantly decreased (Table V). Similarly, PMN directly obtained from subjects 5 min after administration of epinephrine manifested attenuated adherence to endothelial cell monolayers $(46 \pm 3 \%$ preepinephrine compared with $29 \pm 3 \%$ postepinephrine).

\section{DISCUSSION}

The effects of epinephrine on causing a rise in the peripheral PMN count were first noted over 70 yr ago (16). These observations have been confirmed by many workers $(2,17)$; some have suggested that the source of the additional PMN in the bloodstream arises from the release of PMN from the marginating pool $(1,2)$. The development of techniques for establishing in vitro cultures of human endothelial cells $(13,14)$ allowed the study of the interaction of PMN with endothelial cells, leading to an understanding of some of the mechanisms involved in PMN adherence, which likely reflects $\mathrm{PMN}$ margination in vivo (5).

The role traditionally assigned to the endothelial cell was that of a rather passive lining of the lumen of the vessels. Recent findings, however, suggest a much more active physiological role for the endothelial component of the vessel wall. Bevan and co-workers (18) have suggested that adrenergic receptors may be present in the tunica intima of rabbit aorta, and that internal endothelial cells may play a role in regulating changes in vascular diameter induced by blood-born vasoactive agents. Buonassisi and Venter (19) studied endothelium cultured from rabbit aorta and found a catecholamine-stimulated cyclic AMP response that could be fully blocked by the $\beta$-adrenergic antagonist propanolol. Similarly, Herbst and his associates (20) found that norepinephrine increased cyclic AMP formation in an incubated suspension of brain microvessels that could be abolished with propanolol.

In the present study, the ability to culture human endothelial cell monolayers provided the means to investigate some factors regulating PMN endothelial cell interaction. Supernates derived from endothelial cells exposed to the $\beta$-agonist epinephrine and isoproteronal-impaired PMN adhere to both nylon fibers and fresh endothelial cell monolayers. Employing the former assay to monitor PMN adherence, the effect of the postepinephrine supernate was directly linked to the length of exposure and dose of epinephrine, and 
was observed at a concentration of epinephrine achievable in vivo (21-23). Furthermore, the response of the endothelial cell monolayers to epinephrine was dependent upon the activity of their $\beta$ rather than $\alpha$-receptors.

Paralleling the in vitro observations, sera recovered from subjects receiving epinephrine attenuated PMN adherence to both endothelial cell monolayers or to nylon fiber columns, similar to findings of others obtained with postepinephrine plasma by employing the latter technique (24). The inhibitory activity found in the postepinephrine sera diminished over a 30-min interval. Administration of propanolol to subjects at concentrations known to prevent the rise in plasma cyclic AMP (10) prevented the increase in PMN counts as well as led to retention of normal adherent properties after epinephrine injection. Direct exposure of PMN to epinephrine in vitro failed to affect their adherent properties, which likely relates to the inability of epinephrine to substantially raise intracellular cyclic AMP levels (24). Exposure of the PMNendothelial cell overlay to epinephrine led to diminished PMN adherence. Furthermore, once PMN encountered postepinephrine sera, their attenuated adherent properties could be preserved by maintaining the cells at ice bath temperature for $1 \mathrm{~h}$, which parallels the time and temperature conditions required for recovering and purification of PMN from the blood of subjects administered epinephrine.

It would appear from the results of both the in vitro and in vivo studies employing the epinephrine antagonist, propanolol, that the soluble inhibitory factor is cyclic AMP. To confirm this hypothesis, both the postepinephrine sera and the supernate derived from endothelial cell monolayers were incubated with anticyclic nucleotide antibodies. It was only in the presence of anticyclic AMP antisera but not anticyclic GMP antisera that the inhibitory effect of PMN adherence was completely abrogated. The observation that cyclic AMP found in the postepinephrine sera in this study is capable of impairing PMN adherence parallels the in vitro observation by others that cyclic AMP added to PMN will attenuate their adherence to both nylon fibers and endothelial cell monolayers (5). These findings indicate that $\beta$-receptors on endothelial cells are stimulated by epinephrine to release cyclic AMP, which in turn could attenuate PMN adherence to endothelial vasculature thereby leading to a rise in circulating PMN during epinephrine administration.

\section{ACKNOWLEDGMENTS}

We would like to thank the nursing staff of Saint Vincent's Hospital for providing the umbilical cords and Dr. John Hoak and associates of the University of Iowa for their help and encouragement.

This work was supported by a grant from the James Whit- comb Riley Memorial Foundation. This work was done during the tenure of an Established Investigatorship (American Heart Association) by Dr. Boxer.

\section{REFERENCES}

1. Athens, J. W., O. P. Haab, S. O. Raab, A. M. Mauer, H. Ashenbrucker, G. E. Cartwright, and M. M. Wintrobe. 1961. Leukokinetic studies. IV. The total blood circulating in marginal granulocyte pools and a granulocyte turnover rate in normal subjects. J. Clin. Invest. 40: 989-995.

2. Athens, J. W. Granulocyte kinetics in health and disease. 1972. Human Tumor Cell Kinetics. Natl. Cancer Inst. Monogr. 30: 135-156.

3. Grant, L., P. Palmer, and A. G. Saunders. 1962. The effect of heparin on the sticking of white cells to endothelium in inflammation. J. Pathol. Bacteriol. 83: 127-133.

4. Atherton, A., and G. V. R. Born. 1972. Quantitative investigations of the adhesiveness of circulating polymorphonuclear leukocyte to blood vessel walls. $J$. Physiol. (Lond.). 222: 447-474.

5. MacGregor, R. J., E. Macarak, and N. A. Kafalides. 1978. Comparative adherence of granulocytes to endothelial monolayers and nylon fibers. J. Clin. Invest. 61: 697-702.

6. Hoover, R. L., R. T. Briggs, and M. J. Karnovsky. 1978. The adhesive interaction between polymorphonuclear leukocytes and endothelial cells in vitro. Cell. 14: 423-428.

7. Beesley, J. E., J. D. Pearson, J. S. Carleton, A. Hutchings, and J. L. Gordon. 1978. Interaction of leukocytes with vascular cells in culture. J. Cell. Sci. 33: 85-101.

8. Boxer, L. A., J. M. Allen, A. M. Watanabe, H. R. Besch, and R. L. Baehner. 1978. Role of microtubules in granulocyte adherence. Blood. 51: 1045-1050.

9. Boxer, L. A., M. Yoder, S. Bonsib, M. Schmidt, P. Ho, R. Jersild, and R. L. Baehner. 1979. Effects of a chemotactic factor, $\mathrm{N}$-formylmethionyl peptide, on adherence, superoxide anion generation, phagocytosis, and microtubule assembly of human polymorphonuclear leukocytes. J. Lab. Clin. Med. 93: 506-514.

10. Ball, J. H., N. I. Kaminsky, J. G. Hardman, A. E. Broadus, E. W. Sutherland, and G. W. Liddle. 1972. Effects of catecholamines and adrenergic-blocking agents on plasma and urinary cyclic nucleotides in man. J. Clin. Invest. 51: 2124-2129.

11. MacGregor, R. R., P. J. Spagnuolo, and A. L. Lentnek. 1974. Inhibition of granulocyte adherence by ethanol, prednisone, and aspirin measured with an assay system. N. Engl. J. Med. 291: 642-646.

12. Boyum, A. 1968. Isolation of mononuclear cells and granulocytes from human blood: isolation of mononuclear cells by one centrifugation and of granulocytes by combining centrifugation and sedimentation at lg. Scand. J. Clin. Lab. Invest. Suppl. 21: 77-89.

13. Czervionke, R. L., J. C. Hoak, and G. L. Fry. 1978. Effect of aspirin on thrombin-induced adherence of platelets to cultured cells from the blood vessel wall. J. Clin. Invest. 62: $847-856$.

14. Jaffe, E. A., R. L. Nachman, C. G. Becker, and C. R. Minick. 1976. Culture of human endothelial cells derived from umbilical veins. Identification by morphologic and immunologic criteria. J. Clin. Invest. 52: 2745-2756.

15. Jaffe, E. A., L. W. Hoyer, and R. L. Nachman. 1973. Synthesis of antihemophiliac factor antigen by cultured human endothelial cells. J. Clin. Invest. 52: 27572764. 
16. Loepes, M., and O. Crouzon. 1904. L'action de l'adrenaline sur le sang.Arch. Med.Exp. Anat. Pathol. 16: 83-108.

17. Steel, C. M., E. B. French, and W. R. C. Aitchison. 1971. Studies on adrenaline-induced leukocytosis in normal man. I. The role of the spleen and of the thoracic duct. Br. J. Haematol. 21 : 413-421.

18. Bevan, J. A., and S. Duckles. 1975. Evidence for alphaadrenergic receptors on intimal endothelium. Blood Vessels. 12: 307-310.

19. Buonassisi, V., and J. C. Venter. 1976. Hormone and neurotransmitter receptors in an established vascular endothelial cell line. Proc. Natl. Acad. Sci. U. S. A. 73: $1612-1616$.

20. Herbst, T. J., M. E. Raichle, and J. A. Ferrendelli. 1979. $\beta$-adrenergic regulation of adenosine $3^{\prime}, 5^{\prime}$-monophosphate concentration in brain microvessels. Science (Wash. D. C.). 204: 330-332.

21. Galbo, H., J. J. Holst, and N. J. Christensen. 1975. Glucagon and plasma catecholamine responses to graded and prolonged exercise in man. J. Appl. Physiol. 38: 70-76.

22. Manhem, P., H. Lecerof, and B. Hokfelt. 1978. Plasma catecholamine levels in the coronary sinus, the left renal vein and peripheral vessels in healthy males at rest and during exercise. Acta Physiol. Scand. 104: 364-369.

23. Garber, A. J., P. E. Cryer, J. V. Santiago, M. W. Haymond, A. S. Pagliara, and D. M. Kipnis. 1976. The role of adrenergic mechanisms in the substrate and hormonal response to insulin-induced hypoglycemia in man. $J$. Clin. Invest. 58: 7-15.

24. MacGregor, R. R. 1977. Granulocyte adherence changes induced by hemodialysis, endotoxin, epinephrine, and glucocorticoids. Ann. Intern. Med. 86: 35-39.

25. Atkinson, J. P., T. J. Sullivan, J. P. Kelly, and C. W. Parker. 1977. Stimulation by alcohols and cyclic AMP in human leukocytes. Possible role of cyclic AMP in the antiinflammatory effects of ethanol. J. Clin. Invest. 60: 284-294. 